\title{
A new unicuspid-toothed species of Hypostomus Lacépède, 1803 (Siluriformes: Loricariidae) from the rio Paraguai basin
}

\author{
Claudio H. Zawadzki ${ }^{1}$, Luiz F. C. Tencatt ${ }^{2}$ and Otávio Froehlich ${ }^{3}$
}

A new unicuspid-toothed armored catfish species of Hypostomus is described from the Bodoquena Plateau, rio Paraguai basin, Mato Grosso do Sul State, Brazil. The new species is distinguished from its congeners, with exception of $H$. fonchii, by having unicuspid teeth (vs. bicuspid teeth); from $H$. fonchii it is distinguished by having median series of lateral plates with $26-27$ (vs. 28 ); by lower number of premaxillary and dentary teeth (7-10 vs. 18-21; 8-13 vs. 18-25, respectively); for possessing more depressed head (head depth 15.8-18.1\% SL vs. 19.1-22.0\% SL); and by the presence of median buccal papilla ( $v s$. absence).

Uma espécie nova de cascudo do gênero Hypostomus com dentes unicuspidados é descrita da Serra da Bodoquena, bacia do rio Paraguai, estado do Mato Grosso do Sul, Brasil. A espécie nova é distinta de suas congêneres, com exceção de $H$. fonchii, pela presença de dentes unicuspidados (vs. bicuspidados); de H. fonchii é distinta por apresentar a série mediana de placas laterais com 26-27 (vs. 28); pelo menor número de dentes pré-maxilares e no dentário (7-10 vs. 18-21; 8-13 vs. 18-25, respectivamente); por possuir cabeça mais deprimida (altura da cabeça $15.8-18.1 \% \mathrm{CP} v s .19 .1-22.0 \% \mathrm{CP}$ ) e pela presença de papilas bucais medianas (vs. ausência).

Key words: Armored catfish, Bodoquena Plateau, Cascudo, Hypostominae, Taxonomy.

\section{Introduction}

Hypostomus Lacépède is the most species-rich genus of the Loricariidae, which currently comprises 130 valid species (Garavello et al., 2012; Zawadzki et al., 2013). There are 11 nominal valid species described from the rio Paraguai basin: H. cochliodon (Kner), H. ternetzi (Boulenger), H. borellii (Boulenger), $H$. boulengeri (Eigenmann \& Kennedy), $H$. latirostris (Regan), H. variostictus (Miranda Ribeiro), H. latifrons Weber, H. piratatu Weber, H. mutucae Knaack, H. peckoltoides Zawadzki, Weber \& Pavanelli, and H. careopinnatus Martins, Marinho, Langeani \& Serra. In addition, H. regani (Ihering), originally described from the upper rio Paraná basin also occurs in the upper rio Paraguai basin (Weber et al., 1992; Veríssimo et al., 2005; Zawadzki, Renesto, Peres \& Paiva, 2008).

The Bodoquena region is drained by the Apa, Formoso, Formosinho, Perdido, Miranda, rio do Peixe, Salobra, and Sucuri rivers, all part of the rio Paraguai basin (Boggiani,
1999; Salles et al., 2006). According to Boggiani (1999) some of those rivers flow through calcareous terrain resulting in a low turbidity and very clear waters. The region is known for its large aquatic biodiversity and endemism (Scremin-Dias et al., 1999). Sabino \& Trajano (1997) described Ancistrus formoso, an albino cave dwelling armored catfish and, then, ten years later Ribeiro et al. (2007) published the discovery of a new characin Oligosarcus perdido from that region.

Examination of specimens of the genus Hypostomus from the rio Perdido, a tributary to rio Apa of the rio Paraguai basin, revealed a population with an unusual pattern of unicuspid teeth. The aim of this paper is to establish it as a new species of Hypostomus from the Bodoquena Plateau.

\section{Material and Methods}

Measurements were made with digital calipers to the nearest $0.1 \mathrm{~mm}$. Methodology and terminology for measurements

${ }^{1}$ Universidade Estadual de Maringá, Departamento de Biologia. Núcleo de Pesquisas em Limnologia, Ictiologia e Aquicultura (Nupélia). Av. Colombo, 5790, 87020-900 Maringá, PR, Brazil. chzawadzki@hotmail.com (corresponding author)

${ }^{2}$ Universidade Estadual de Maringá, Programa de Pós-Graduação em Ecologia de Ambientes Aquáticos Continentais. Av. Colombo, 5790, 87020-900 Maringá, PR, Brazil. luiztencatt@hotmail.com

${ }^{3}$ Universidade Federal de Mato Grosso do Sul, Laboratório de Zoologia/Centro de Ciências Biológicas e da Saúde. Caixa Postal 549, 79070 900 Campo Grande, MS, Brazil. otaviofr@gmail.com 
follow Boeseman (1968) with modifications by Weber (1985) and Zawadzki et al. (2008). Plate counts and nomenclature follow Schaefer (1997), with the modifications of Oyakawa et al. (2005). Vertebral counts were taken on cleared-andstained (c\&s) specimens, according to Taylor \& Van Dyke (1985) procedures. The vertebral complex of the Weberian apparatus and the compound caudal centrum were counted as a single element (Lundberg \& Baskin, 1969). Osteological nomenclature follows Schaefer (1987). Standard length (SL) is expressed in millimeters; some measures are expressed as percents of SL; some as percents of head length (HL) and additionally, some other percents are according to Zawadzki et al. (2010). Meristic and morphometric ranges of the type series of Hypostomus fonchii Weber \& Montoya-Burgos cited in the diagnosis section of the present work are from Weber \& Montoya-Burgos (2002). In Table 1, range is composed by the minimum and maximum values of the holotype, plus 19 paratypes. Institutional abbreviations are: ANSP, Academy of Natural Sciences of Drexel University, Philadelphia; BMNH, Natural History Museum, London; CPUFMT, Coleção de Peixes da Universidade Federal do Mato Grosso, Cuiabá; INPA, Instituto Nacional de Pesquisas da Amazônia, Manaus; MCP, Museu de Ciências e Tecnologia, Pontifícia Universidade Católica do Rio Grande do Sul, Porto Alegre; MHNG, Museum d'histoire naturelle, Geneva; MNHN, Muséum National d'histoire naturelle, Paris; MNRJ, Museu Nacional, Universidade Federal do Rio de Janeiro, Rio de Janeiro; MZUSP, Museu de Zoologia, Universidade de São Paulo, São Paulo; NUP, Coleção Ictiológica do Núcleo de Pesquisas em Limnologia, Ictiologia e Aquicultura da Universidade Estadual de Maringá, Maringá; RMNH, Naturalis Biodiversity Center, Leiden; UMSS, Universidad Mayor de San Simón, Cochabamba; ZSM, Zoologische Staatssammlung München, Munich; ZUEC, Museu de Zoologia da Universidade Estadual de Campinas "Adão José Cardoso", Campinas; ZUFMS-PIS, Coleção Zoológica de Referência da Universidade Federal de Mato Grosso do Sul, Campo Grande.

\section{Results}

\section{Hypostomus perdido, new species Figs. 1-2a,c}

Hypostomus sp. 2-Rio Perdido NUP 4249: Cereali et al., 2008: 587 (cytogenetic data, karyotype).

Holotype. MZUSP 111064, $159.1 \mathrm{~mm}$ SL, Brazil, Mato Grosso do Sul, Bodoquena, rio Paraguai basin, rio Perdido, 21¹7'09'S 5641'47’'W, 8 Sep 2005, O. Froehlich.

Paratypes. All collected with the holotype (61 specimens). ANSP 193370, 2, 163.6-171.3 mm SL. CPUFMT 1500, 2, 152.5-170.3 mm SL. INPA 37689, 1, 144.4 mm SL. MCP 47141, 2, 133.9-147.9 mm
SL. MNRJ 40094, 2, 126.0-153.1 mm SL. NUP 12143, 10, 136.4$166.3 \mathrm{~mm}$ SL. NUP 12144, 18, 109.1-152.4 mm SL. NUP 14406, 1 c\&s, 124.0 mm SL. ZSM 41828, 1, 149.5 mm SL. ZUEC 7254, 2, 140.2-141.7 mm SL. ZUFMS-PIS 1468, 20, 126.6-181.0 mm SL.

Diagnosis. Hypostomus perdido is distinguished from all congeners, except $H$. fonchii, by having unicuspid teeth (vs. bicuspid teeth). From $H$. fonchii it is distinguished by having fewer dermal plates in the median series of lateral plates (2627 vs. 28), fewer premaxillary teeth (7-10 vs. 18-21), fewer dentary teeth (8-13 vs. 18-25), a more depressed head (head depth 15.8-18.1\% in SL vs. 19.1-22.0\%), and by the presence of median buccal papilla ( $v s$. its absence).

Description. Measurements and counts in Table 1. Dorsal profile of head convex from tip of snout to supraoccipital posterior end; straight from that point to dorsal-fin origin. Head elevated and compressed. Snout narrow and compressed, covered by irregular series of several small plates. Mesethmoid forming conspicuous bulge from snout tip to nares. Upper orbital margin not elevated. Eye laterodorsally positioned. Interorbital region wide and flat in frontal view. Very slender keel on upper portion of pteroticsupracleithrum just posterior to orbit. Opercle considerably large and somewhat ellipsoidal; its horizontal length similar to orbital diameter; odontodes slightly larger on posterior margin. Predorsal region almost flat; usually with one single larger plate surrounding supraoccipital followed by two narrow plates in front of dorsal-fin spinelet. Dorsal profile of trunk tapering straight from dorsal-fin insertion to caudal peduncle posterior portion; ascending to caudal fin. Adipose fin long, almost same length of minimum caudal peduncle depth. Maximum body width at region of dorsal-fin origin; profile gradually tapering from this point to caudal fin. Caudal peduncle somewhat ellipsoid in cross-section; dorsal and ventral caudal peduncle region slightly flattened.

Dorsal fin II,7; distal margin slightly convex to straight; origin at vertical two plates before pelvic-fin insertion; adpressed rays not reaching adipose-fin spine. Pectoral fin I,6; distal margin straight and almost reaching from one-third to half pelvic-fin length, odontodes more developed on distal dorsal region. Pelvic fin I,5; distal margin straight to slightly convex; distal portion of unbranched pelvic-fin ray reaching or slightly surpassing anal-fin insertion when adpressed to body. Anal fin I,5; distal border rounded. Caudal fin I,14,I, posterior margin truncate to slight emarginated; lower lobe slightly longer than upper lobe. Vertebrae 27; ribs 9, first rib relatively larger than others.

Dorsal and lateral surface of head and body covered with dermal plates, except snout tip and area surrounding dorsal-fin base. Plates on lateral margin of head, from snout tip to pterotic-supracleithrum small and irregular. Five lateral 
series of plates on trunk. Dorsal, mid-dorsal, median, midventral and ventral series without keels. Lateral line complete on median lateral series. Mid-ventral series moderately bent on anterior portion. Ventral region of body with small platelets bearing odontodes, except area beneath lower lip, insertion of pectoral and pelvic fins, and anterior region of

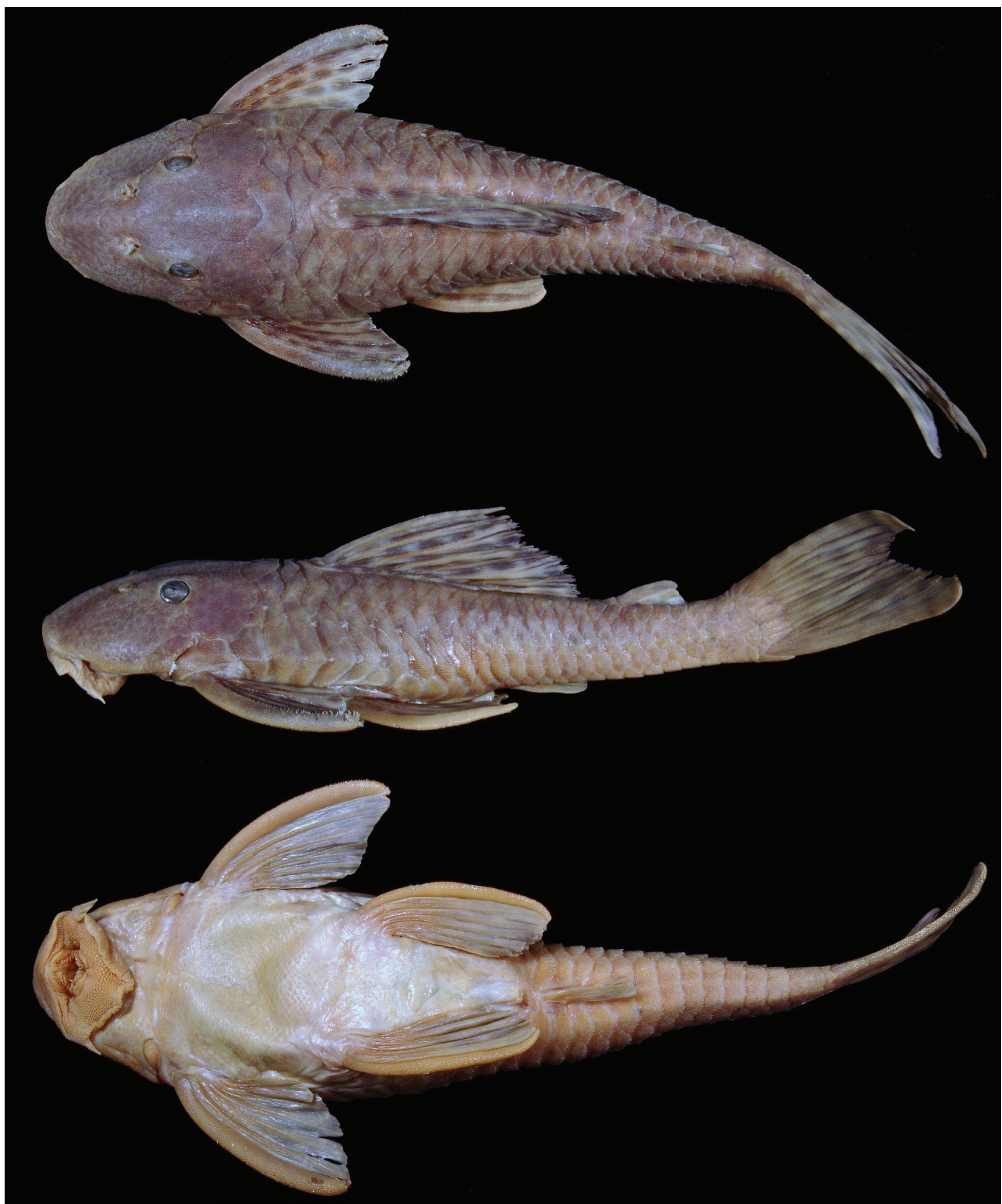

Fig. 1. Hypostomus perdido, holotype, MZUSP 111064, $159.1 \mathrm{~mm}$ SL, Brazil, Mato Grosso do Sul State, Bodoquena, rio Paraguai basin, rio Perdido. Dorsal (top), lateral (middle), and ventral (bottom) views. 
anus. Naked areas reduced on larger specimens. Lips round; covered with dense papillae, which decrease in size to distal border. Median buccal papilla sensu Armbruster (2003, fig. 3 ) present. Buccal skin internally bordering premaxilla and dentary with unorganized series of flat enlarged papillae (Fig. 2a,c). Maxillary barbel elongate and proximately joined to labial border by membrane; distal tip free. Premaxilla with 7 to 10 teeth, dentary 8 to 13 teeth; teeth robust, moderate in length, unicuspid, crown short and continuous to stalk (without notch between stalk and crown). Dentary rami straight and angled 82 to $94^{\circ}$ from each other $(n=20$ specimens; mean $=85.8^{\circ}$ ).

Color in alcohol. Dorsal ground color of body and fins grayish brown. Trunk and fins densely covered by faint darker spots; spots smaller on head and larger on fins and posterior portions of body. All spines and unbranched-fin rays with spots. Dorsal, pectoral, and pelvic fins with one series of spots on each interradial membrane. Dorsal-fin spots usually larger than spots in remaining fins and usually aligned to form five to seven horizontal bands; spots mottled in some specimens. Anal-fin spots more faded than remaining fin spots. Abdominal region pale yellowish. Ventral surface of body and paired fins spotless.

Distribution. The new species is known from its type locality, the rio Perdido, tributary to the rio Apa, rio Paraguai basin, Mato Grosso do Sul State, Brazil (Fig. 3).
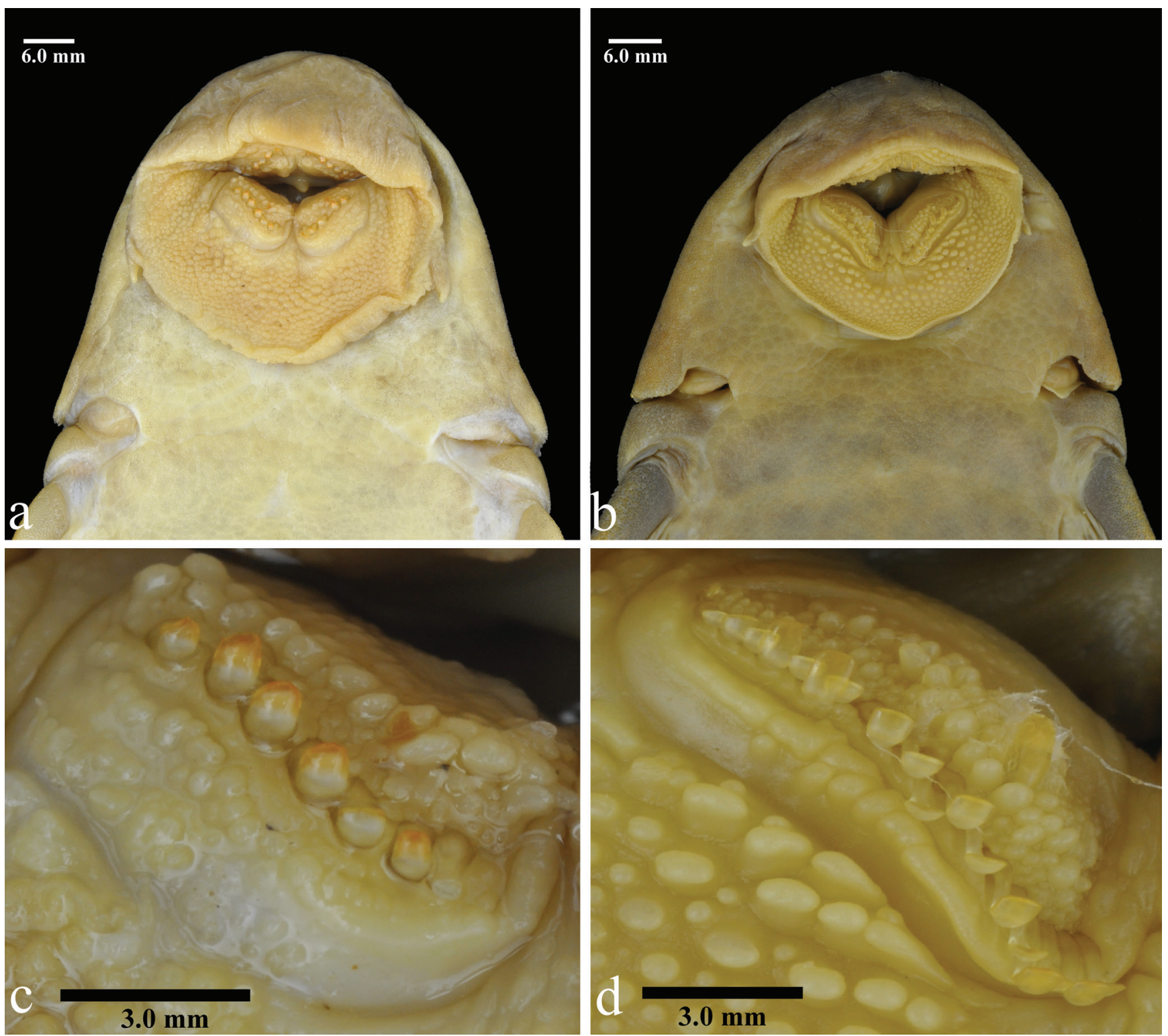

Fig. 2. Mouth and right dentary close up of Hypostomus perdido, paratype, CPUFMT 1500, $170.3 \mathrm{~mm}$ SL (a and c) and of Hypostomus fonchii UMSS 00360, $154.0 \mathrm{~mm}$ SL (b and d), respectively. 
Table 1. Morphometric data and counts of Hypostomus perdido. $\mathrm{SD}=$ standard deviation; $\mathrm{N}=$ holotype plus 19 specimens.

\begin{tabular}{|c|c|c|c|}
\hline & Holotype & Range & Mean/SD \\
\hline Standard length & 159.1 & $137.3-171.3$ & $154.6 \pm 10.1$ \\
\hline \multicolumn{4}{|c|}{ Percents of standard length } \\
\hline Predorsal length & 37.0 & $36.1-39.2$ & $37.7 \pm 0.9$ \\
\hline Head length & 30.1 & 28.7-31.6 & $30.4 \pm 0.8$ \\
\hline Cleithral width & 25.9 & $25.9-27.9$ & $27.1 \pm 0.6$ \\
\hline Head depth & 16.8 & $15.8-18.1$ & $17.0 \pm 0.7$ \\
\hline Interdorsal length & 16.3 & $14.9-18.7$ & $16.5 \pm 0.9$ \\
\hline Thoracic length & 21.3 & $17.4-25.1$ & $20.9 \pm 0.9$ \\
\hline Abdominal length & 24.1 & $21.7-25.3$ & $23.5 \pm 0.9$ \\
\hline Dorsal-fin spine length & 26.1 & $23.4-29.7$ & $26.8 \pm 1.6$ \\
\hline Pectoral-fin spine length & 26.6 & 26.2-29.0 & $27.7 \pm 0.7$ \\
\hline Pelvic-fin unbranched ray length & 23.4 & $23.0-26.2$ & $24.7 \pm 0.8$ \\
\hline Caudal-peduncle length & 34.3 & $30.0-35.8$ & $33.5 \pm 1.1$ \\
\hline Caudal-peduncle depth & 9.0 & $8.6-10.1$ & $9.3 \pm 0.3$ \\
\hline \multicolumn{4}{|c|}{ Percents of head length } \\
\hline Cleithral width & 89.8 & 84.3-94.8 & $89.4 \pm 2.4$ \\
\hline Head depth & 55.7 & $52.3-60.2$ & $56.0 \pm 2.0$ \\
\hline Snout length & 63.5 & $60.2-67.4$ & $62.8 \pm 1.6$ \\
\hline Orbital diameter & 15.7 & $15.1-17.8$ & $16.1 \pm 0.6$ \\
\hline Interorbital width & 36.7 & $32.7-39.3$ & $36.1 \pm 1.8$ \\
\hline Mandibullary width & 13.2 & $13.2-18.4$ & $15.6 \pm 1.4$ \\
\hline \multicolumn{4}{|c|}{ Other percents } \\
\hline Orbital diameter in snout length & 24.7 & $24.7-27.1$ & $25.8 \pm 1.0$ \\
\hline Orbital diameter in interorbital width & 42.6 & $42.6-47.3$ & $44.8 \pm 2.0$ \\
\hline Mandibullary width in interorbital width & 35.8 & $35.8-46.9$ & $40.5 \pm 5.0$ \\
\hline First dorsal-fin spine length in predorsal length & 70.6 & $69.7-75.4$ & $71.5 \pm 2.7$ \\
\hline First pectoral-fin spine length in predorsal length & 72.1 & $72.1-75.4$ & $74.3 \pm 1.5$ \\
\hline Lower caudal-fin unbranched ray length in predorsal length & 85.2 & $81.2-88.3$ & $85.2 \pm 3.0$ \\
\hline Adipose-fin spine length in caudal-peduncle depth & 96.5 & $96.5-105.9$ & $99.7 \pm 4.2$ \\
\hline Caudal-peduncle depth in caudal-peduncle length & 26.2 & $26.2-29.1$ & $27.5 \pm 1.2$ \\
\hline Mandibullary width in cleithral width & 14.7 & $14.7-19.2$ & $16.4 \pm 2.0$ \\
\hline Interdorsal length in dorsal-fin base length & 67.7 & $62.7-73.3$ & $67.9 \pm 4.6$ \\
\hline Lower lip width in lower lip length & 35.5 & $31.1-42.6$ & $36.0 \pm 4.8$ \\
\hline \multicolumn{4}{|l|}{ 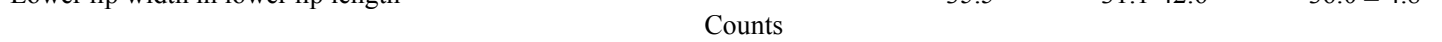 } \\
\hline & Holotype & Range & Mode \\
\hline Median plate series & 26 & $26-27$ & 26 \\
\hline Predorsal plates & 3 & 3 & 3 \\
\hline Plates bordering supraoccipital & 1 & 1 & 1 \\
\hline Dorsal plates below dorsal-fin base & 7 & 7 & 7 \\
\hline Plates between dorsal and adipose fin & 8 & $6-8$ & 7 \\
\hline Plates between adipose and caudal fin & 7 & $7-8$ & 7 \\
\hline Plates between anal-fin base and caudal fin & 11 & 11 & 11 \\
\hline Premaxillary teeth & 8 & $7-10$ & 9 \\
\hline Dentary teeth & 8 & $8-13$ & 10 \\
\hline
\end{tabular}

Ecological notes. The upper $50 \mathrm{~km}$ of the rio Perdido flows from elevations of $550 \mathrm{~m}$ to $350 \mathrm{~m}$ through the calcareous Bodoquena Plateau. It initially flows to the southeast, passes about 2 to $3 \mathrm{~km}$ as subterranean portion, then turns roughly southwards and bisects the Parque Nacional da Serra da Bodoquena, where the river flows confined in open folds of the Paraguai Fold Belt. Then the river turns to the southwest, descends the plateau escarpments and flows $250 \mathrm{~km}$ further before discharging in the rio Apa, at roughly $100 \mathrm{~m}$ altitude. In the plateau, the river is 10 to $12 \mathrm{~m}$ wide and is dammed by several calcareous tufa deposits, some of them forming waterfalls from one to five meters high. The dammed sections can be as deep as $12 \mathrm{~m}$, with vertical rock banks and very slow flow; the substrate is a whitish calcareous clay on which lay many submerged logs, branches and even whole trees. The water is very clear throughout the dry season. However, transparency is significantly reduced in the rainy season, mainly due to suspended clay. Specimens of Hypostomus perdido were collected in stretches of sluggish to still waters.

Etymology. The specific name perdido alludes to the type locality rio Perdido. From the Portuguese "perdido", which means lost. An adjective nominative, masculine, and singular.

\section{Discussion}

The unusual teeth morphology of Hypostomus perdido distinguishes the new species not only from its congeners from the rio Paraguai basin, but from nearly all species of the genus. The only exception is $H$. fonchii, described from the west tributaries to the middle río Ucayali in Peru, which also has unicuspid teeth (Fig. 2b and 2d). Hypostomus fonchii (Fig. 4) also inhabits Bolivian streams flowing to the rio Mamoré. Despite the tooth similarity, H. perdido is more depressed than 
H. fonchii, has less dermal plates on the median series and less teeth on premaxilla and on dentary. Weber \& MontoyaBurgos (2002) addressed $H$. fonchii to the $H$. cochliodon group due to its unicuspid tooth pattern. Armbruster (2003) noted that the species of $H$. cochliodon group did not possess unicuspid teeth but bicuspid teeth with lateral cusp usually fused to mesial cusp and rejected a close relationship with $H$. fonchii because the body morphology did not agree with the typical body shape of the members of the $H$. cochliodon group. Armbruster (2003) also commented that specimens of $H$. fonchii were not examined by him, in that work. Herein, we verified the tooth morphology of $H$. fonchii finding clearly unicuspid teeth, but it is anyway much slender than the teeth of $H$. perdido.

Montoya-Burgos et al. (2002) performed a phylogenetic analysis based on mitochondrial D-loop sequences data and recovered Hypostomus fonchii within the H. cochliodon group of species, corroborating the initial proposition of Weber \& Montoya-Burgos (2002). The position of $H$. fonchii within the $H$. cochliodon group of species was also maintained in Montoya-Burgos (2003). Therefore, we consider H. fonchii somewhat morphologically compatible with the H. cochliodon group species. Contrary to $H$. fonchii, $H$. perdido indeed does not resemble representatives of the $H$. cochliodon group of species, since it possesses slender body ( $v s$. robust) and rounded snout ( $v s$. triangular). In addition, the new species presents dentary rami angled to each other from 82 to $94^{\circ}$ versus less than $80^{\circ}$ in the species of the $H$. cochliodon group. To elucidate the phylogenetic relationships of the new species a cladistic analysis based on morphological and/or molecular data would be necessary. However, considering the aforementioned differences, it would be plausible that unicuspid teeth character had arisen independently.

Cytogenetic data are already available to Hypostomus perdido. The species was named as "Hypostomus sp 2-Rio Perdido NUP 4249" by Cereali et al. (2008). Except $H$. perdido, the diploid number in Hypostomus ranges from 54 to 82 (Bueno et al., 2012). Cereali et al. (2008) found H. perdido with 84 chromosomes $(2 n=84)$, as the greatest diploid number known in Hypostomus (Martinez et al., 2011; Rubert et al., 2011; Endo et al., 2012; Bueno et al., 2013).

Comparative material. Hypostomus ancistroides. Brazil. São Paulo State. Rio Paraná basin. MZUSP 2131, 4, 95.6-165.1 mm SL, rio Tatuí. Hypostomus borellii. Bolivia. Rio Paraguai basin. BMNH 1897.1.27.19, 1, $153.1 \mathrm{~mm}$ SL, syntype, río Pilcomayo. Hypostomus boulengeri. Brazil. Mato Grosso State. Rio Paraguai basin. NUP 414, 3, 165.8-175.6 mm SL; NUP 3273, 8, 110.0-166.0 mm SL; NUP 8695, 1, $170.0 \mathrm{~mm}$ SL, rio Manso. NUP 1078, 2, 210.0-220.0 mm SL, rio Manso Reservoir. NUP 8692, 1, 190.0

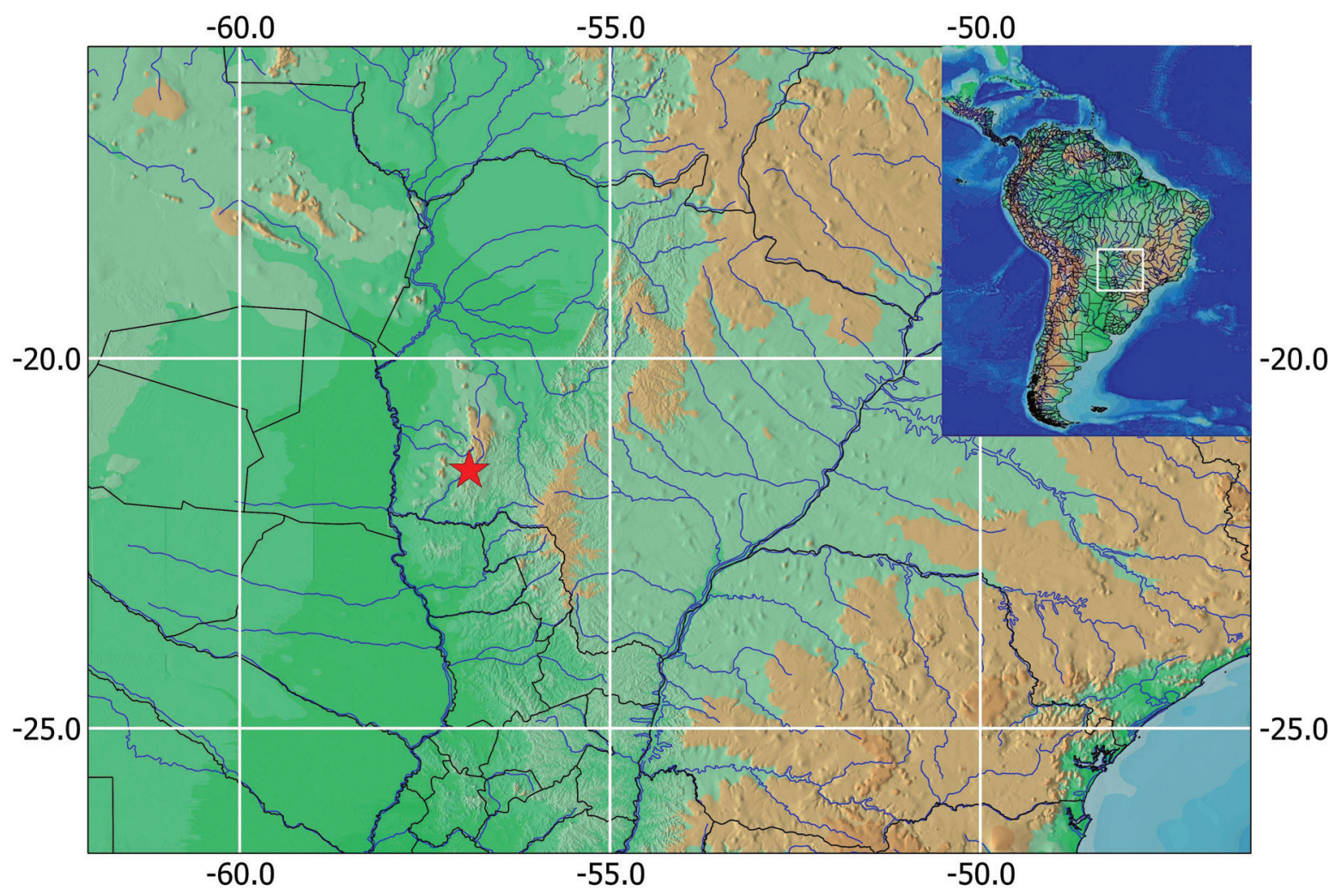

Fig. 3. Distribution of Hypostomus perdido. Red star symbol represents its type locality, the rio Perdido, rio Paraguai basin, Mato Grosso do Sul State, Brazil. Inset in the right upper corner highlights the area into a South American perspective. 


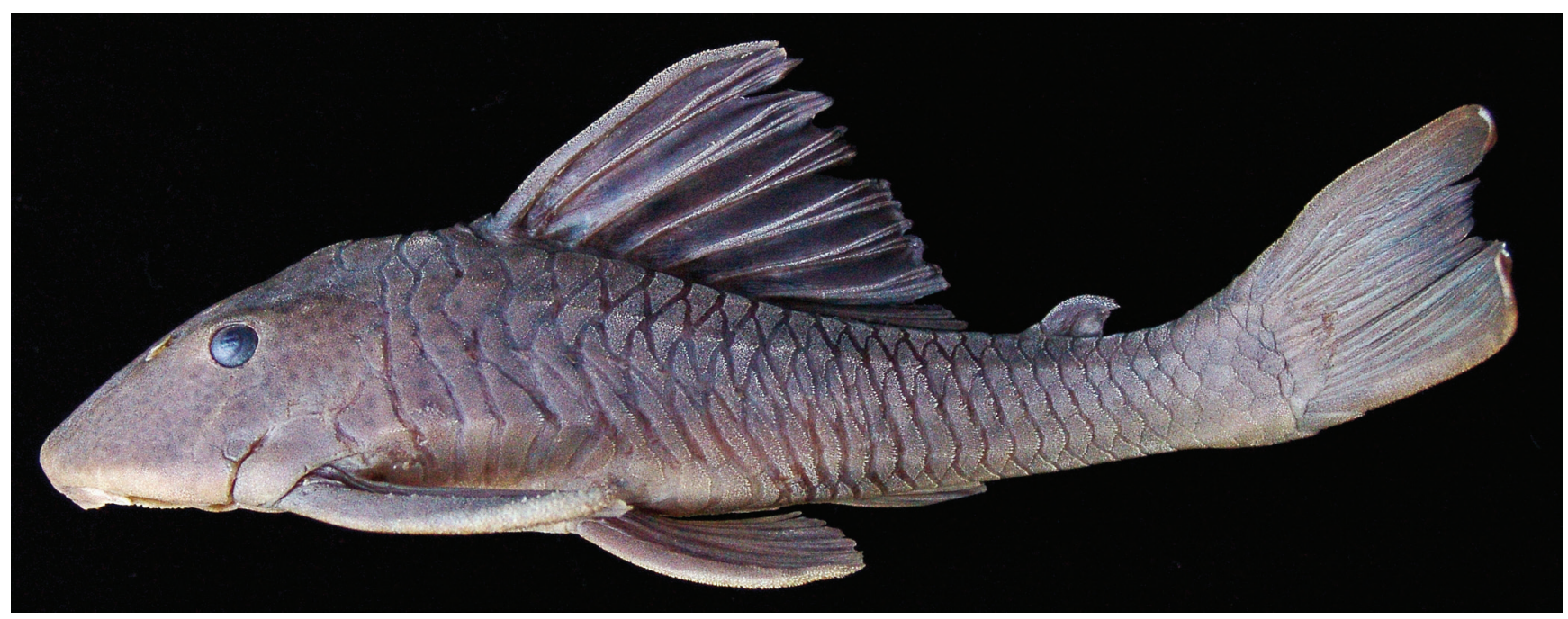

Fig. 4. Lateral view of Hypostomus fonchii, UMSS 00360, $154.0 \mathrm{~mm}$ SL, río Chipiriri, río Mamoré basin, Bolivia.

$\mathrm{mm}$ SL, rio Quilombo. Hypostomus careopinnatus. Brazil. Mato Grosso State. Rio Paraguai basin. NUP 11257, 5, 30.2-53.8 mm SL, paratypes, tributary of rio Ariranha. Hypostomus cochliodon. Brazil. Mato Grosso State. Rio Paraguai basin. NUP 2274, 2, 42.2-200.4 mm SL; NUP 3602, 1, 153.8 mm SL; NUP 2274, 2, 42.2-200.4 mm SL, rio Manso. Hypostomus commersoni. Uruguay. Montevideo Department. Río de La Plata basin. MNHN A.9444, 1, $425.00 \mathrm{~mm}$ SL, holotype, río de la Plata. Hypostomus dlouhyi. Paraguay. Alto Paraná Department. Río Paraná basin. MHNG 2229.43, 1, $139.5 \mathrm{~mm} \mathrm{SL}$, holotype, río Yguazú. Hypostomus fonchii. Bolivia. Río Mamoré basin. UMSS 00360, 1, $154.0 \mathrm{~mm}$ SL, río Chipiriri. Peru. San Martin Department. Río Ucayali basin. MHNG 2613.066, 141.0 mm SL, holotype, Quebrada John, near mouth of río Pauya. Hypostomus laplatae. Argentina. Río de La Plata basin. BMNH 1908.8.29.17, 1, 207.3 mm SL, río de La Plata. Hypostomus latifrons. Brazil. Mato Grosso State. Rio Paraguai basin. NUP 1039, 3, 240.0-260.0 mm SL, rio Manso Reservoir. NUP 3405, 1, 270.0 mm SL, Sinhá Mariana bay. Paraguay. Presidente Hayes Department. Río Paraguai basin. MHNG 2256.67, 228.2 mm SL, holotype, río Araguay-guazú. Hypostomus latirostris. Brazil. Mato Grosso State. Rio Paraguai basin. BMNH 1892.4.20.26-27, 2, 137.2-159.3 mm SL, syntypes, rio Jangada. NUP 12203, 1, 113.0 $\mathrm{mm}$ SL, rio Casca. NUP 12204, 1, $55.0 \mathrm{~mm} \mathrm{SL}$, rio Manso. NUP 12205, 2, 75.0-120.0 mm SL, rio Cuiabá; NUP 12206, 1, 104.0 mm SL, rio Palmeiras; NUP 12323, 1, $109.0 \mathrm{~mm} \mathrm{SL}$, rio Cuiabazinho. Hypostomus microstomus. Paraguay. Itapua Department. Rio Paraná basin. MHNG 2367.90, 197.5 mm SL, holotype, río Paraná. Hypostomus mutucae. Brazil. Mato Grosso State. Rio Paraguai basin. MCP 28669, $67.7 \mathrm{~mm}$ SL, holotype, rio Mutuca. NUP 6641, 13, 52.4-109.2 mm SL; NUP 6642, 4, 62.1-98.1 mm SL, rio Claro. Hypostomus nigromaculatus. Brazil. São Paulo State. Rio Paraná basin. MZUSP 22674, 9, 43.8-75.9 mm SL, cachoeira de Emas, rio Mogi-Guaçu. Hypostomus paranensis. Argentina. Cordoba Department. Río Paraná basin. BMNH 1878.4.4.1, 178.3 mm SL, holotype of Plecostomus cordovae, río Paraná. MZUSP 23805, 6, 47.5-111.3 mm SL, río Segundo, Pilar, río Paraguay basin. Hypostomus peckoltoides. Brazil. Mato Grosso State. Rio Paraguai basin. NUP 5216, 2, 88.9-92.8 mm SL; NUP 5217, 3, 85.5-98.2 mm SL; MZUSP 105226, 110.7 mm SL, holotype, rio Cuiabá. Hypostomus piratatu. Paraguay. Paraguarí Department. Río Paraguay basin. MHNG 2265.03, 214.0 mm SL, holotype, río Paraguai. Hypostomus plecostomus. Suriname. RMNH 18240, 1, 121.4 mm SL, Suriname Rivier. Hypostomus regani. Brazil. Mato Grosso State. Rio Paraguai basin. NUP 1032, 3, 260.0-270.0 mm SL, Manso Reservoir. NUP 7917, 3, 92.0-107.0 mm SL, rio Ariranha. NUP 8325, 1, 130.0 mm SL, córrego Roncador. Mato Grosso do Sul State. Rio Paraguai basin. NUP 9820, 2, 129.5-37.7 mm SL, córrego da Onça. São Paulo State. Rio Paraná basin. BMNH 1905.6.7.3, 174.2 mm SL, holotype, rio Piracicaba. Hypostomus ternetzi. Brazil. Mato Grosso State. Rio Paraguai basin. BMNH 1895.5.17.64, 210.2 mm SL, holotype, rio Paraguai.

\section{Acknowledgments}

We are grateful to Fernando Jerep (MZUEL), Héctor Vera-Alcaraz, and Richard Kleinhardt for their comments and suggestions for the manuscript; to Marcel Cavallaro, Ismael Escote and Emanuele Pomini for helping during scuba observations; to Maria José Vilela, Renata Vargas, Ottilie Forster and Nereida de Almeida for help during collecting trips. Thanks are also due to Mark Sabaj-Pérez (ANSP), Patrick Campbell (BMNH), Carlos Lucena and Margarete Lucena (MCP), Claude Weber and Sonia Fisch-Muller (MHNG), Patrice Pruvost (MNHN), Paulo Buckup and Marcelo Britto (MNRJ), Osvaldo Oyakawa (MZUSP), Dirk Neumann (ZSM) and Fernando Carvajal (UMSS) for loan of comparative material and hosting museum visits. Nupélia provided us with logistical support. Visits to museum collections by $\mathrm{CHZ}$ were 
funded by the All Catfish Species Inventory (DEB-0315963). CAPES (Coordenação de Aperfeiçoamento de Pessoal de Nível Superior) provided grants to LFCT. CNPq (Conselho Nacional de Desenvolvimento Científico e Tecnológico) provided a grant to CHZ (Proc. 310733/2013-8).

\section{Literature Cited}

Armbruster, J. W. 2003. The species of the Hypostomus cochliodon group (Siluriformes: Loricariidae). Zootaxa, 249: 1-60.

Boeseman, M. 1968. The genus Hypostomus Lacépède, 1803, and its Surinam representatives (Siluriformes, Loricariidae). Zoologische Verhandelingen, 99: 1-89.

Boggiani, P. C. 1999. Por que Bonito é Bonito? - Geologia da Serra da Bodoquena. Pp. 10-23. In: Scremin-Dias, E., V. J. Pott, R. C. Hora \& P. R. Souza (Eds.). Nos Jardins Suspensos da Bodoquena - Guia para Identificação de Plantas Aquáticas de Bonito e Região. Campo Grande, Editora da UFMS.

Bueno, V. S., P. C. Venere, C. H. Zawadzki \& V. P. Margarido. 2013. Karyotype diversification in Hypostomus Lacépède, 1803 (Osteichthyes, Loricariidae): biogeographical and phylogenetic perspectives. Reviews in Fish Biology and Fisheries, 23: 103-112.

Bueno, V. S., C. H. Zawadzki \& V. P. Margarido. 2012. Trends in chromosome evolution in the genus Hypostomus Lacépède, 1803 (Osteichthyes, Loricariidae): a new perspective about the correlation between diploid number and chromosomes types. Reviews in Fish Biology and Fisheries, 22: 241-250.

Cereali, S. S., E. Pomini, R. Rosa, C. H. Zawadzki, O. Froehlich \& L. Giuliano-Caetano. 2008. Karyotype description of two species of Hypostomus (Siluriformes, Loricariidae) of the Planalto da Bodoquena, Brazil. Genetics and Molecular Research, 7: 583-591.

Endo, K. S., E. R. M. Martinez, C. H. Zawadzki, L. R. S. Paiva \& H. F. Júlio Jr. 2012. Karyotype description of possible new species of the Hypostomus ancistroides complex (Teleostei: Loricariidae) and other Hypostominae. Acta Scientiarum. Biological Sciences, 34: 181-189.

Garavello, J. C., H. A. Britski \& C. H. Zawadzki. 2012. The cascudos of the genus Hypostomus Lacépède (Ostariophysi: Loricariidae) from the rio Iguaçu basin. Neotropical Ichthyology, 10: 263-283.

Lundberg, J. G. \& J. N. Baskin. 1969. The caudal skeleton of the catfishes. Order Siluriformes. American Museum Novitates, 2398: 1-49.

Martinez, E. R. M., C. H. Zawadzki, F. Foresti \& C. Oliveira. 2011. Cytogenetic analysis of five Hypostomus species (Siluriformes, Loricariidae). Genetics and Molecular Biology, 34: 562-568.

Montoya-Burgos, J. I. 2003. Historical biogeography of the catfish genus Hypostomus (Siluriformes: Loricariidae), with implications on the diversification of Neotropical ichthyofauna. Molecular Ecology, 12: 1855-1867.

Montoya-Burgos, J. I., C. Weber \& P-Y. Le Bail. 2002. Phylogenetic relationship within Hypostomus (Siluriformes: Loricariidae) and related genera based on mitochondrial D-loop sequences. Revue suisse de Zoologie, 109: 369-382.

Oyakawa, O. T., A. Akama \& A. M. Zanata. 2005. Review of the genus Hypostomus Lacépède, 1803 from Rio Ribeira de Iguape basin, with description of a new species (Pisces, Siluriformes, Loricariidae). Zootaxa, 921: 1-27.

Ribeiro, A. C., M. R. Cavallaro \& O. Froehlich. 2007. Oligosarcus perdido (Characiformes, Characidae), a new species of freshwater fish from Serra da Bodoquena, upper Rio Paraguai basin, Brazil. Zootaxa, 1560: 43-53.
Rubert, M., R. da Rosa, F. C. Jerep, L. A. C. Bertollo \& L. GiulianoCaetano. 2011. Cytogenetic characterization of four species of the genus Hypostomus Lacépède, 1803 (Siluriformes, Loricariidae) with comments on its chromosomal diversity. Comparative Cytogenetics, 5: 397-410.

Sabino, J. \& E. Trajano. 1997. A new species of blind armoured catfish, genus Ancistrus, from caves of Bodoquena region, Mato Grosso do Sul, southwestern Brazil. Revue Française d'Aquariologie, 24: 73-78.

Salles, L. O., C. Cartelle, P. G. Guedes, P. C. Boggiani, A. Janoo \& C. A. M. Russo. 2006. Quaternary mammals from Serra da Bodoquena, Mato Grosso do Sul, Brazil. Boletim do MuseuNacional, 521: 1-12.

Schaefer, S. A. 1987.Osteology of Hypostomus plecostomus (Linnaeus), with a phylogenetic analysis of the loricariid subfamilies (Pisces: Siluroidei). Contributions in Science, 394: 1-31.

Schaefer, S. A. 1997. The Neotropical cascudinhos: systematics and biogeography of the Otocinclus catfishes (Silurifiormes: Loricariidae). Proceedings of the Academy of Natural Sciences of Philadelphia, 148: 1-120.

Scremin-Dias, E., V. J. Pott, R. C. Hora \& P. R. Souza. 1999. Nos jardins submersos da Bodoquena: guia de identificação de plantas aquáticas de Bonito e região. Campo Grande, Editora da UFMS.

Taylor, W. R. \& G. C. Van Dyke. 1985. Revised procedures for staining and clearing small fishes and other vertebrates for bone and cartilage study. Cybium, 9: 107-119.

Veríssimo, S., C. S. Pavanelli, H. A. Britski \& M. M. M. Moreira. 2005. Fish, Manso Reservoir region of influence, Rio Paraguai basin, Mato Grosso State, Brazil. Check List, 1: 1-9.

Weber, C. 1985. Hypostomus dlouhyi, nouvelle espèce de poisson-chat cuirassé du Paraguay (Pisces, Siluriformes, Loricariidae). Revue suisse de Zoologie, 92: 955-968.

Weber, C., S. Muller \& V. Mahnert. 1992. Harnischwelse Paraguays. DATZ (Sonderheft Harnischwelse): 10-13.

Weber, C. \& J. I. Montoya-Burgos. 2002. Hypostomus fonchii sp. n. (Siluriformes: Loricariidae) from Peru, a key species suggesting the synonymy of Cochliodon with Hypostomus. Revue suisse de Zoologie, 109: 355-368.

Zawadzki, C. H., J. L. O. Birindelli \& F. C. T. Lima. 2008. A new pale-spotted species of Hypostomus Lacépède (Siluriformes: Loricariidae) from the rio Tocantins and Xingu basins in central Brazil. Neotropical Ichthyology, 6: 395-402.

Zawadzki, C. H., R. R. de Oliveira \& T. Debona. 2013. A new species of Hypostomus Lacépède, 1803 (Siluriformes: Loricariidae) from the rio Tocantins-Araguaia basin, Brazil. Neotropical Ichthyology, 11: 73-80.

Zawadzki, C. H., E. Renesto, M. D. Peres \& S. Paiva. 2008. Allozyme variation among three populations of the armored catfish Hypostomus regani (Ihering, 1905) (Siluriformes: Loricariidae) from the Paraná and Paraguay river basins, Brazil. Genetics and Molecular Biology, 31: 767-771.

Zawadzki, C. H., C. Weber \& C. S. Pavanelli. 2010. A new darksaddled species of Hypostomus (Siluriformes: Loricariidae) from the upper rio Paraguay basin. Neotropical Ichthyology, 8: 719-725. 